Красинский Владислав Вячеславович

доктор юридических наук, член Общественного

консультативного научно-методического Совета

при ЦИК России

109012, г. Москва, Б. Черкасский пер. д. 4 стр. 2

\title{
Несовершенство миграционного законодательства и угрозы национальной безопасности Российской Федерации
}

Красинский B.B. Несовершенство миграционного законодательства и угрозы национальной безопасности Российской Федерации // Современное право. 2013. № 2; www.krasinskiy.ru

Аннотация: В статье анализируется российское миграционное законодательство и угрозы национальной безопасности Российской Федерации. Автор изучает характеристики миграционного законодательства и дает предложения по его совершенствованию в интересах национальной безопасности.

Ключевые слова: миграционное законодательство, угрозы национальной безопасности, незаконная миграция, проблемы государственной миграционной политики.

The article examines the Russian migratory legislation and threats of national security of the Russian Federation. The author studies characteristics of the migratory legislation and gives offers on its improvement.

Key words: migratory legislation, threats of national security, illegal migration, problems of the state migratory policy.

Особенности современных миграционных процессов в Российской Федерации неразрывно связаны с угрозами её национальной безопасности.

В настоящее время российская территория активно используется выходцами из стран с нестабильной внутриполитической и экономической обстановкой в качестве убежища, оседания на постоянное жительство, а также для осуществления незаконной трудовой деятельности, включая торговлю оружием и наркотиками, переправку рабочей силы в зарубежные страны ${ }^{1}$.

С учетом масштаба рынка труда мигрантов в Российской Федерации и сращивания национальных анклавов с криминальными структурами нелегальная рабочая сила стала неотъемлемой частью организованного преступного бизнеса. Под влиянием роста численности этнических диаспор, пополняемых за счет мигрантов, формируются предпосылки к возникновению межэтнических и межконфессиональных конфликтов. Неконтролируемый приток иностранцев негативно влияет на криминогенную обстановку в крупных административных и промышленных центрах, серьёзно меняет национальный состав населения ряда регионов страны и ставит под угрозу этническую, культурную и территориальную целостность Российской Федерации.

1 Предмет статьи не охватывает вопросы гражданства и статуса вынужденных переселенцев. 
Реализации данных угроз национальной безопасности способствует наличие ряда факторов, к числу которых следует отнести:

техническую необустроенность и незавершенность договорноправового оформления значительных участков Государственной границы Российской Федерации с государствами СНГ;

проявления коррупции в субъектах государственной миграционной политики, способствующие незаконной миграции в Российской Федерации';

упрощенный порядок въезда на территорию Российской Федерации граждан некоторых иностранных государств;

несовершенство системы миграционного учета и контроля за въездом, выездом и пребыванием иностранных граждан и лиц без гражданства на территории Российской Федерации.

Состояние национальной безопасности Российской Федерации в миграционной сфере во многом обусловлено качеством российского миграционного законодательства, которое не позволяет противостоять существующим угрозам².

Оценка состояния миграционных процессов и национальной безопасности Российской Федерации была дана в работах С.А. Антошкина, О.В. Дамаскина, С.Г. Евтушенко, В.А. Золотарёва, В.М. Редкоуса, К.Б. Фатеева и др. ${ }^{3}$

Проблемы государственной миграционной политики и противодействия незаконной миграции освещены в работах Г.В. Антонова-

${ }^{1}$ В качестве незаконной миграции автор рассматривает незаконный въезд, выезд, пребывание (проживание) или транзитный проезд через территорию государства в целях оседания на постоянное жительство либо временного пребывания на территории той или иной страны.

2 Под миграционным законодательством Российской Федерации понимается совокупность общепризнанных принципов и норм международного права, законодательных и подзаконных нормативных правовых актов, регламентирующих общественные отношения, возникающие при осуществлении въезда, транзитного проезда, передвижения (пребывания) на территории Российской Федерации либо выезда из Российской Федерации иностранных граждан и лиц без гражданства (далее миграционные отношения).

${ }^{3}$ Антошкин С.A. Этнополитические процессы в Дальневосточном регионе Российской Федерации и их влияние на пограничную безопасность: дис. ... канд. полит, наук. М., 2010. 195 с.; Бимал Г. Суверенитет, безопасность и открытые границы // Миграция без границ / под ред. А. Пеку, П. Де Гуштена. М., 2009. С. 159-163; Дамаскин $O . B$. Россия в современном мире: проблемы национальной безопасности: монография. М., 2007. 429 с.; Евтушенко С.Г. Правовое обеспечение военной безопасности России: дис. ... канд. юрид. наук. М., 2000. 199 с.; Золотарёв B.A. Военная безопасность России: политико-правовые проблемы: дис. ... д-ра юрид. наук. М., 1999. 198 с.; Национальная безопасность и миграционная политика // Аналитический вестник Совета Федерации Федерального Собрания Российской Федерации. М., 2005. № 22; Редкоус В.M. Формирование законодательства в области миграции государств - участников СНГ и вопросы обеспечения национальной безопасности // Миграционное право. 2007. № 1; Фатеев К.В. Обеспечение военной безопасности Российской Федерации: теория и практика правового регулирования: монография. М., 2005. С. 51. 
Романовского, В.М. Баранова, И.С. Викторова, И.Н.Гавриловой, К.Д. Галиахметовой, О.В. Дамаскина, В.Е.Подшивалова, О.Н. Шерстобоева и др ${ }^{1}$.

Миграционное право как элемент системы российского права рассматривала Т.Я. Хабриева ${ }^{2}$. Конституционно-правовые аспекты регулирования миграционных отношений, основы правового статуса мигрантов в Российской Федерации исследовали Н.Н. Анисимова, В.П. Басик, К.Д. Галиахметова, Р.Р. Искандеров, Т.В. Кочуков, М.Д. Оздоев, И.В Плюгина, Б.С Эбзеев и др ${ }^{3}$.

Сфера правового регулирования миграционных отношений в контексте обеспечения национальной безопасности Российской Федерации предметом самостоятельных научных исследований не являлась.

В связи с этим характеристика российского миграционного законодательства и изучение её взаимосвязи с состоянием национальной безопасности Российской Федерации представляются актуальными.

Как отмечается в Концепции государственной миграционной политики Российской Федерации на период до 2025 года, утвержденной Президентом Российской Федерации 13 июня 2012 года, «миграционное законодательство Российской Федерации не в полной мере соответствует текущим и будущим потребностям экономического, социального и демографического развития, интересам работодателей и российского общества в целом. Оно ориентировано на привлечение временных иностранных работников и не

${ }^{1}$ Антонов-Романовский Г.В., Викторов И.С., Галиахметова К.Д. и др. Прокуратура в системе обеспечения законности миграционного процесса в Российской Федерации / Под ред. д-ра юрид. наук О.В. Дамаскина. М., 2008; Баранов В.M. Незаконная миграция в современной России: понятие, виды, эффективность противодействия // Миграция, права человека и экономическая безопасность современной России: состояние, проблемы, эффективность защиты. Н. Новгород, 2004. С. 49; Гаврилова И.Н. К проблеме государственной миграционной политики в Российской Федерации // Государственная власть и местное самоуправление. 2007. № 8; Подшивалов B.E. Международно-правовые проблемы предупреждения и пресечения незаконной миграции: Дис. ...канд. юрид. наук. СПб, 2004. 170 с; Шерстобоев О.Н. Принцип пропорциональности как необходимое условие высылки иностранных граждан за пределы государства их пребывания: пределы правоограничения // Рос. юрид. Журнал. 2011. № 6.

2 Хабриева Т.Я. Миграционное право как структурное образование российского права // Журнал российского права. 2007. № 11; Хабриева Т.Я. Миграционное право России: теория и практика. М., 2008.

${ }^{3}$ Анисимова Н.Н. Правовой статус беженцев: Дис. ... канд. юрид. наук. М., 2002; Басик В.П. Правовое положение граждан Российской Федерации и иностранцев в России. M., 2004; Галиахметова К.Д. Конституционно-правовое регулирование положения мигрантов в Российской Федерации: Дис. ... канд. юрид. наук. М., 2006; Искандеров Р.P. Правовой статус беженцев в Российской Федерации: Дис. ... канд. юрид. наук. М., 2006; Кочуков T.B. Конституционно-правовой статус иностранных граждан и лиц без гражданства в Российской Федерации: Дис. ... канд. юрид. наук. М., 2004; Оздоев М.Д. Конституционно-правовой статус вынужденных переселенцев и беженцев в Российской Федерации: Дис. ... канд. юрид. наук. М., 2003; Плюгина И.В. Теоретические основы правового статуса мигрантов // Журнал российского права. 2009. № 3; Эбзеев Б.С. Миграция населения в теоретико-правовом аспекте // Журнал российского права. 2008. № 5. 
содержит мер, способствующих переезду на постоянное место жительства, адаптации и интеграции мигрантов»1.

Несовершенство системы правового регулирования миграционными процессами проявляется в наличии большого числа незаконных мигрантов. Так, ежегодно в стране от 3 до 5 миллионов иностранных граждан осуществляют трудовую деятельность без официального разрешения ${ }^{2}$.

Неспособность существующих правовых механизмов обеспечить адаптацию и интеграцию мигрантов приводит к их изоляции от общества и вовлечению в преступную деятельность. Статистические данные ГИЦ МВД России свидетельствуют о том, что на протяжении последних 10 лет наблюдается устойчивый рост преступлений, совершаемых иностранцами и лицами без гражданства ${ }^{3}$. Большая часть преступлений, совершаемых иностранцами, приходятся на граждан государств СНГ - 81\% именно граждане ближнего зарубежья чаще всего становятся и жертвами преступных посягательств.

В Концепции государственной миграционной политики Российской Федерации справедливо отмечается, что «незаконная миграция, питающая рабочей силой теневой сектор экономики, является одной из главных причин усиления негативного отношения к мигрантам со стороны части населения Российской Федерации».

Правовая регламентация миграционных отношений в интересах национальной безопасности Российской Федерации осуществляется на основе общепризнанных принципов и норм международного права. В частности, в Декларации о правах человека в отношении лиц, не являющихся гражданами страны, в которой они проживают 1985 г. и Протоколе против незаконного ввоза мигрантов по суше, морю и воздуху к Конвенции ООН против транснациональной организованной преступности 2000 г. признается право государств на принятие мер по противодействию незаконной миграции, регулированию въезда иностранцев и условий их пребывания.

Важным международным договором, предусматривающим взаимодействие по вопросам борьбы с незаконной миграцией в формате СНГ, является Соглашение о сотрудничестве государств - участников Содружества Независимых Государств в борьбе с незаконной миграцией (Москва, 6 марта 1998 г.) ${ }^{5}$. Незаконные мигранты, выявленные на территории одного из государств - участников Соглашения, подлежат депортации в

${ }^{1}$ Концепция государственной миграционной политики Российской Федерации на период до 2025 года (утв. Президентом Российской Федерации 13 июня 2012 года) // Выше право. Миграция. 2012. № 13.

${ }^{2}$ Там же.

3 Электронный ресурс - http://www.demoscope.ru/weekly/2009/0363/analit04.php.

${ }^{4}$ Бастрыкин А.И. Противодействие преступности мигрантов - один из основных факторов укрепления безопасности России // Журнал Право и безопасность - электронный pecypc - http://www.psj.ru/saver_magazins/detail.php?ID=23608. 2009, 17 ноября.

5 Содружество: Информационный вестник Совета глав государств и Совета глав правительств СНГ. 1998. № 1. 
государство выезда в соответствии с национальным законодательством государства въезда, если иное не предусмотрено международными договорами. В случае, если незаконные мигранты прибыли на территорию одной стороны с территории другой стороны, они, при наличии соответствующих доказательств, подлежат передаче последней. При этом передача незаконных мигрантов осуществляется в соответствии с отдельными договоренностями.

Особым фрагментом правовой базы противодействия незаконной миграции в интересах национальной безопасности являются реадмиссионные соглашения и двусторонние договоры о сотрудничестве по пограничным вопросам ${ }^{1}$.

Наряду с международно-правовым регулированием национальный блок миграционного законодательства Российской Федерации содержит ряд правовых механизмов, регламентирующих миграционные отношения в интересах обеспечения национальной безопасности. Указанные механизмы представлены:

- юридическими нормами, ограничивающими въезд в Российскую Федерацию отдельных категорий иностранных граждан и лиц без гражданства (имеющих неснятую или непогашенную судимость за совершение умышленных преступлений в Российской Федерации; подвергавшихся выдворению (депортации); переданных иностранному государству в порядке реадмиссии в период предыдущего пребывания в России; иностранцев, в отношении которых принято решение о нежелательности пребывания (проживания) в Российской Федерации и др.; установление Правительством Российской Федерации квот на выдачу иностранным гражданам приглашений на въезд в Российскую Федерацию в целях осуществления трудовой деятельности; установление миграционными органами запрета на въезд в Российскую Федерацию отдельных иностранных граждан и лиц без гражданства);

- юридическими нормами, определяющими правосубъектность (ограничения отдельных прав) временно пребывающих в Российской Федерации иностранных граждан и лиц без гражданства (установление Правительством Российской Федерации квот на выдачу иностранным гражданам разрешений на временное проживание в Российской Федерации;

${ }^{1}$ Правительством Российской Федерации заключены реадмиссионные соглашения с Правительством Литовской Республики (2003), Европейским сообществом (2006), Кабинетом Министров Украины (2006), Правительством Королевства Норвегия (2007), Правительством Республики Узбекистан (2007), Правительством Королевства Дания (2008), Правительством Исландии (2008), Правительством Социалистической Республики Вьетнам (2008), Федеральным Советом Швейцарской Конфедерации (2009), Правительством Республики Армения (2010), Правительством Турецкой Республики (2011) и Правительством Республики Казахстан (2012). Двусторонние договоры о сотрудничестве по пограничным вопросам заключены Российской Федерацией с Республикой Беларусь (1994), Республикой Болгария (1998), Республикой Молдова (1998), Киргизской Республикой (1999), Республикой Узбекистан (2001) и Социалистической Республикой Вьетнам (2008). 
отказ в выдаче либо аннулирование разрешения на временное проживание; сокращение Правительством Российской Федерации срока временного пребывания; принятие решения о нежелательности пребывания иностранного гражданина в Российской Федерации);

- юридическими нормами, определяющими правосубъектность (ограничения отдельных прав) постоянно проживающих в Российской Федерации иностранных граждан (отказ в выдаче либо аннулирование вида на жительство; принятие решения о нежелательности проживания иностранного гражданина в Российской Федерации);

- юридическими нормами, ограничивающими передвижение иностранных граждан и лиц без гражданства в пределах Российской Федерации (разрешительный порядок посещения отдельных территорий, организаций и объектов, перечень которых утвержден Правительством Российской Федерации);

- юридическими нормами, регулирующими трудовую деятельность иностранных работников в Российской Федерации (ограничения на допуск иностранных граждан к деятельности и замещению должностей в соответствии с федеральным законом; установление Правительством Российской Федерации квот на выдачу иностранным гражданам разрешений на работу; установление Правительством Российской Федерации допустимой доли иностранных работников в различных отраслях экономики; отказ в выдаче и аннулирование разрешения на работу);

- юридическими нормами, регулирующими выезд из Российской Федерации иностранных граждан и лиц без гражданства (ограничения на выезд иностранцев из Российской Федерации до принятия решения по уголовному делу, до вступления в законную силу приговора суда; до отбытия (исполнения) наказания или до освобождения от наказания; до исполнения обязательств; выдворение (депортация) иностранного гражданина за пределы Российской Федерации; передача иностранного гражданина в соответствии с международным договором о реадмиссии; установление срока выезда из Российской Федерации при принятии Правительством Российской Федерации решения о сокращении срока временного пребывания иностранных граждан).

Правовые ограничения на въезд, пребывание (проживание), трудовую деятельность или транзитный проезд через территорию Российской Федерации установлены в отношении: лиц, выступающих за насильственное изменение основ конституционного строя Российской Федерации; представляющих угрозу безопасности Российской Федерации; пособников террористической (экстремистской) деятельности; лиц, подвергавшихся выдворению (депортации) за пределы Российской Федерации; имеющих неснятую или непогашенную судимость за совершение умышленных преступлений в Российской Федерации; переданных иностранному государству в порядке реадмиссии в период предыдущего пребывания в России; иностранцев, в отношении которых принято решение о нежелательности пребывания (проживания) в Российской Федерации; 
неоднократно привлекавшихся к административной ответственности в Российской Федерации за нарушение режима пребывания (проживания) иностранных граждан в Российской Федерации; совершивших административное правонарушение, связанное с незаконным оборотом наркотических средств или психотропных веществ и их прекурсоров; лиц, представивших поддельные или подложные документы либо сообщивших о себе заведомо ложные сведения.

Данные ограничения правосубъектности являются адекватными, пропорциональными, соразмерными и необходимыми для защиты конституционных ценностей ${ }^{1}$.

Вместе с тем, несмотря на общую положительную направленность правовой регламентации миграционных отношений в интересах обеспечения национальной безопасности Российской Федерации, следует констатировать, что данный комплекс правовых норм реализуется недостаточно эффективно.

Для того, чтобы оценить реальное состояние национальной безопасности Российской Федерации в миграционной сфере, оптимизировать существующую систему иммиграционного контроля и усовершенствовать юридические механизмы реализации государственной миграционной политики Российской Федерации, следует определить характеристики миграционного законодательства Российской Федерации.

Выявление соответствующих характеристик миграционного законодательства осуществляется в формате правового мониторинга законодательства и его применения, а также при проверке органами конституционного правосудия конституционности оспариваемых положений нормативных актов и рассмотрении жалоб на нарушение конституционных прав человека и гражданина в сфере миграции.

Как представляется, основные характеристики миграционного законодательства Российской Федерации включают:

- состояние разработанности понятийно-категориального аппарата;

- полноту правового регулирования порядка въезда, транзитного проезда, передвижения (пребывания) на территории Российской Федерации, а также выезда из Российской Федерации иностранных граждан и лиц без гражданства;

- степень урегулированности трудовой деятельности иностранных граждан и лиц без гражданства в Российской Федерации;

- степень согласованности законодательных и подзаконных актов в сфере миграционных отношений;

1 О конституционности отдельных ограничений прав и свобод человека и гражданина см. Зорькин В.Д. Угрозы международной и национальной безопасности и ограничение прав человека в практике конституционного правосудия // Российское правосудие. 2006. № 2; Эбзеев Б.С. Человек, народ, государство в конституционном строе Российской Федерации. М.: Юрид. лит-ра, 2005. с. 232-234; Эбзеев Б.С. Личность и государство в России: взаимная ответственность и конституционные обязанности. М.: Норма, 2007. С. 257-259. 
- степень регламентации порядка привлечения к уголовной и административной ответственности за нарушение миграционного законодательства Российской Федерации.

Одной из характеристик миграционного законодательства является единство его понятийно-терминологической системы.

В действующем миграционном законодательстве недостаточно подробно изложен понятийный аппарат, что приводит к неоднозначному толкованию правовых норм. В частности, в главе 2 Федерального закона «О порядке выезда из Российской Федерации и въезда в Российскую Федерацию» не определено понятие приглашающей стороны, не закреплены её обязанности и ответственность в случае приглашения иностранца, цель въезда которого не соответствует заявленной.

В соответствии со ст.2 Федерального закона «О правовом положении иностранных граждан в Российской Федерации» под понятие «иностранный работник» не подпадает категория временно проживающих в Российской Федерации иностранных граждан, работающих на основании трудовых или гражданско-правовых договоров.

Нечеткое определение ключевых понятий и отсутствие единой понятийно-терминологической системы миграционного законодательства позволяет работодателям временно проживающих в Российской Федерации иностранных граждан уклоняться от контроля миграционных органов.

Ключевой характеристикой миграционного законодательства выступает полнота правового регулирования общественных отношений, возникающих при осуществлении въезда, транзитного проезда, передвижения (пребывания) на территории Российской Федерации либо выезда из Российской Федерации иностранных граждан и лиц без гражданства.

В российском законодательстве отсутствует комплексный подход к регулированию миграционных отношений.

Миграционное законодательство практически не регламентирует миграционные потоки из государств-участников СНГ с безвизовым въездом или упрощенным порядком оформления въездных виз.

В законодательстве не предусмотрена обязательная процедура дактилоскопирования иностранных мигрантов. В соответствии со ст. 33 Федерального закона «О правовом положении иностранных граждан в Российской Федерации» обязательной дактилоскопической регистрации подлежат только две категории иностранных граждан: незаконно находящиеся в Российской Федерации и подлежащие приему (передаче) в соответствии с международным договором о реадмиссии.

В Федеральном законе 2006 г. «О миграционном учете иностранных граждан и лиц без гражданства в Российской Федерации» у принимающей стороны нет обязанности уведомлять миграционные органы об убытии иностранного гражданина из адреса, что позволяет мигрантам бесконтрольно пребывать на территории Российской Федерации и осуществлять незаконную деятельность. 
В жилищном законодательстве не предусмотрены ограничения на количество возможных регистраций граждан по одному адресу. Данное обстоятельство используется для официальной регистрации значительного количества мигрантов по одному адресу (т.н. «резиновые адреса») ${ }^{1}$.

Наличие правовых пробелов, противоречий и отсутствие единообразной практики применения нормативных правовых актов в миграционной сфере умело используются организаторами нелегальной миграции для получения неконтролируемых государством финансовых средств за оказание иностранцам услуг по организации незаконного въезда, пребывания и транзитного проезда по территории Российской Федерации.

На состояние национальной безопасности в миграционной сфере непосредственное влияние оказывает полнота правового регулирования трудовой деятельности иностранных граждан и лиц без гражданства в Российской Федерации.

В настоящее время отсутствуют специальные программы сезонной трудовой миграции. Действующая система квотирования не обеспечивает привлечения иностранных работников на рабочие места в соответствии с заявленной потребностью работодателей.

Требуется совершенствование порядка привлечения физическими лицами иностранных работников для личных, домашних и иных подобных нужд на основании патентов для осуществления трудовой деятельности.

Важной проблемой правоприменения является организация въезда и пребывания иностранных граждан по ходатайствам фиктивных фирм, от имени которых осуществляется приглашение иностранных граждан в Россию и их последующая легализация. Указанные организации не осуществляют хозяйственную деятельность, а их номинальные учредители и руководители зачастую даже не осведомлены о существовании соответствующих фирм.

Существенно осложняет борьбу с незаконными мигрантами постановка иностранцев на миграционный учёт через отделения почтовой связи с предъявлением копий документов, удостоверяющих личность. Данная ситуация привела к появлению в субъектах Российской Федерации коммерческих структур, оказывающих иностранным гражданам за материальное вознаграждение услуги по их постановке на миграционный учёт с нарушением установленного порядка.

При оценке состояния национальной безопасности Российской Федерации в миграционной сфере и качества законодательства необходимо учитывать степень согласованности законодательных и подзаконных актов, регулирующих миграционные отношения.

В ряде случаев федеральные законы в рассматриваемой сфере противоречат друг другу. Так, в соответствии с п.1 ст. 6.1 Федерального закона 2002 г. «О правовом положении иностранных граждан в Российской

${ }^{1}$ Как показывает практика, иностранные граждане по данным адресам фактически не проживают. Их пребывание принимающей стороной не контролируется. 
Федерации» разрешение на временное проживание в Российской Федерации может быть выдано любому иностранному гражданину, законно находящемуся на территории Российской Федерации. Однако, согласно статьям 25.6 и 25.8 Федерального закона 1996 г. «О порядке выезда из Российской Федерации и въезда в Российскую Федерацию» для въезда и пребывания на территории Российской Федерации иностранному гражданину в целях осуществления трудовой деятельности или временного проживания необходима не частная, а рабочая виза, либо виза временно проживающего лица.

Ключевой характеристикой правового регулирования миграционных отношений в контексте обеспечения национальной безопасности Российской Федерации является степень регламентации порядка привлечения к уголовной и административной ответственности за нарушение миграционного законодательства Российской Федерации.

Действующим административно-правовым режимом въезда и пребывания иностранных граждан и лиц без гражданства не предусмотрена возможность прекращения приема документов от организаций, ранее допускавших нарушения российского миграционного законодательства.

Нуждается в регулировании порядок задержания, привлечения к административной ответственности и выдворения иностранных граждан из числа нелегальных мигрантов, не имеющих при себе документов, удостоверяющих личность. Зная о существовании временных ограничений по установлению личности (не более 3 часов) и практике отказа судей рассматривать дела об административных правонарушениях без подтверждения личности правонарушителя, иностранцы прячут свои документы с целью уклонения от наказания.

Нормативными актами не регламентирован порядок расходования денежных средств на исполнение решений о нежелательности пребывания (проживания) иностранцев на территории Российской Федерации.

Отсутствует системный подход в части применения административного выдворения мигрантов, совершивших правонарушения. В настоящее время иностранный гражданин, нарушивший режим пребывания в Российской Федерации, может быть выдворен в административном порядке. В то же время, иностранцы, совершившие преступления, не выдворяются за пределы Российской Федерации после отбывания наказания.

Законодательные и ведомственные акты в миграционной сфере позволяют уклоняться незаконным мигрантам от уголовной ответственности по ст. 322 УК РФ «Незаконное пересечение Государственной границы Российской Федерации» в случае задержания не по месту незаконного пересечения границы. Отсутствуют механизмы привлечения к ответственности лиц, выдворенных из Российской Федерации и не имеющих разрешения на въезд, в случае замены документов, удостоверяющих личность, с изменением установочных данных. Не предусмотрена возможность применения принудительных мер по выполнению решения о 
нежелательности пребывания в Российской Федерации к иностранным гражданам и лицам без гражданства, освобожденным из мест лишения свободы. Указанные недостатки миграционного законодательства существенно затрудняют работу правоохранительных органов Российской Федерации по противодействию использованию каналов миграции в ущерб интересам национальной безопасности.

Как уже отмечалось, выявление характеристик миграционного законодательства осуществляется не только в формате правового мониторинга, но и при проверке органами конституционного правосудия оспариваемых положений нормативных правовых актов и рассмотрении жалоб на нарушение прав иностранных граждан в сфере миграции.

Конституционный Суд Российской Федерации рассматривал жалобы иностранных граждан на нарушение их конституционных прав Федеральным законом «О правовом положении иностранных граждан в Российской Федерации», предусматривающим аннулирование разрешения на временное проживание (отказ в выдаче такого разрешения) в случае неоднократного привлечения к административной ответственности за нарушение законодательства в части обеспечения режима пребывания (проживания) иностранных граждан в Российской Федерации ${ }^{1}$.

Так, в Определении Конституционного Суда Российской Федерации от 2 марта 2006 г. № 55-О «По жалобе гражданина Грузии Тодуа К. на нарушение его конституционных прав п.7 ст.7 Федерального закона «О правовом положении иностранных граждан в Российской Федерации» отмечается, что установление ответственности за нарушение порядка пребывания (проживания) иностранных граждан в Российской Федерации должно отвечать требованиям справедливости, соразмерности конституционно закрепленным целям (ч.3 ст. 55 Конституции Российской Федерации), а также характеру совершенного деяния.

В решении по данной жалобе Конституционный Суд признал, что пункт 7 статьи 7 Федерального закона «О правовом положении иностранных граждан в Российской Федерации», предполагающий при решении вопроса о выдаче или об аннулировании разрешения на временное проживание иностранному гражданину, неоднократно (два и более раза) в течение одного года привлекавшемуся к административной ответственности за нарушение законодательства в части обеспечения режима пребывания (проживания) иностранных граждан в Российской Федерации, учет уполномоченными органами исполнительной власти и судом личности этого иностранного гражданина, его семейного положения, характера и степени общественной опасности совершенных им административных правонарушений, не может рассматриваться как нарушающий конституционные права и свободы.

${ }^{1}$ Вестник Конституционного Суда Российской Федерации. 2006. № 4. 
Данная правовая позиция соответствует практике Европейского Суда по правам человека, который в своих постановлениях от 26 марта 1992 года по делу «Бельджуди (Beldjoudi) против Франции», от 21 июня 1988 года по делу «Беррехаб (Berrehab) против Нидерландов», от 18 февраля 1991 года по делу «Мустаким (Moustaquim) против Бельгии», от 19 февраля 1998 года по делу «Далиа (Dalia) против Франции», от 7 августа 1996 года по делу «С. против Бельгии», от 28 ноября 1996 года по делу «Ахмут (Ahmut) против Нидерландов» и др. отмечал, что лежащая на государствах ответственность за обеспечение публичного порядка обязывает их контролировать въезд в страну и пребывание иностранцев и высылать за пределы страны правонарушителей из их числа, однако подобные решения, поскольку они могут нарушить право на уважение личной и семейной жизни должны быть оправданы крайней социальной необходимостью и соответствовать правомерной цели.

В Определении Конституционного Суда Российской Федерации от 30 сентября 2010 г. № 1317-О-П «По жалобе Закарии Мусы Ясира Мустафы, Маланга Сулеймана и ряда других иностранных граждан на нарушение их конституционных прав пп. 2 п. 2 ст. 12 Федерального закона «О беженцах» рассматривалась правовая природа временного убежища, предоставляемого беженцам, соотношение данного института с общим порядком получения разрешения на пребывание (проживание) в Российской Федерации и правомерность выдворения (депортации) по истечении срока временного убежища ${ }^{1}$.

Конституционный Суд пришел к выводу, что временное убежище, предоставляемое в соответствии с Федеральным законом «О беженцах», является мерой дополнительной защиты, препятствующей выдворению (депортации) лиц, не имеющих законных оснований для пребывания на территории Российской Федерации, однако в силу сложной жизненной ситуации временного характера вынужденных находиться на территории Российской Федерации. Данный институт носит экстраординарный характер и действует наряду с общими основаниями легализации пребывания (проживания) иностранных граждан и лиц без гражданства на территории Российской Федерации.

Временное убежище не может рассматриваться как альтернатива общему порядку получения разрешения на пребывание (проживание) на территории Российской Федерации при наличии у лица оснований для легализации своего правового положения на территории Российской Федерации в обычном порядке.

По мнению Конституционного Суда, предоставление иностранному гражданину и лицу без гражданства временного убежища на территории Российской Федерации возможно только при исчерпании предусмотренных

\footnotetext{
${ }^{1}$ Вестник Конституционного Суда Российской Федерации. 2011. № 2
} 
законодательством механизмов получения разрешения на пребывание (проживание) на территории Российской Федерации. Решение вопроса в пользу иностранного гражданина или лица без гражданства не лишает уполномоченный орган исполнительной власти права по истечении срока временного убежища поставить вопрос о его (выдворении) депортации, при том что такие лица вправе вернуться в Российскую Федерацию и оформить разрешение на пребывание (проживание) на ее территории в рамках законодательства о правовом положении иностранных граждан в Российской Федерации.

Предпринятая в данной статье попытка оценить состояние национальной безопасности Российской Федерации в миграционной сфере свидетельствует о наличии проблем, обусловленных недостатками российского миграционного законодательства.

В связи с этим предлагается ряд мер по совершенствованию миграционного законодательства Российской Федерации с учетом интересов обеспечения национальной безопасности.

- в Федеральных законах «О порядке выезда из Российской Федерации и въезда в Российскую Федерацию», «О правовом положении иностранных граждан в Российской Федерации» ввести обязательную государственную дактилоскопическую регистрацию при оформлении и выдаче иностранным гражданам и лицам без гражданства документов для въезда в Российскую Федерацию с последующим помещением полученных сведений в центральный банк данных;

- в Федеральном законе «О правовом положении иностранных граждан в Российской Федерации» определить понятие приглашающей стороны, закрепить ее обязанность уведомлять миграционные органы об убытии иностранных граждан и лиц без гражданства из адреса;

- в Постановлении Правительства Российской Федерации от 22 декабря 2006 г. № 783 «О порядке определения исполнительными органами государственной власти потребности в привлечении иностранных работников и формирования квот на осуществление иностранными гражданами трудовой деятельности в Российской Федерации» закрепить обязанность приглашающих организаций при подаче заявок в исполнительные органы власти субъектов Российской Федерации представлять материалы, подтверждающие факт ведения хозяйственной деятельности (справки из налоговых органов о размере уплаченных налогов в текущем году; хозяйственные договоры, подтверждающие выполнение работ по виду деятельности, указанному в заявке на квоту);

- в Федеральном законе «О правовом положении иностранных граждан в Российской Федерации» предусмотреть возможность прекращения приема документов от приглашающих организаций, допускавших в течение года неоднократные нарушения миграционного законодательства Российской Федерации;

- исключить процедуру миграционного учета иностранных граждан и лиц без гражданства в помещениях по юридическим адресам предприятий и 
организаций. В этих целях в Федеральном законе «О миграционном учете иностранных граждан и лиц без гражданства в Российской Федерации» от 18 июля 2006 года № 109-Ф3 закрепить обязанность принимающей стороны обеспечивать постановку трудовых мигрантов на миграционный учет по месту их пребывания в помещениях, пригодных для постоянного проживания и соответствующих установленным санитарным нормам;

- ввести административную ответственность служащих организаций федеральной почтовой связи за прием уведомлений о прибытии иностранных граждан в место пребывания без наличия у иностранцев документов, удостоверяющих личность;

- в Федеральном законе «О порядке выезда из Российской Федерации и въезда в Российскую Федерацию», Постановлении Правительства Российской Федерации от 4 апреля 2003 г. № 193 «Об утверждении правил определения квоты на выдачу иностранным гражданам разрешений на временное проживание в Российской Федерации» предусмотреть установление единой ежегодной квоты на временное проживание иностранцев в Российской Федерации (за исключением лиц, признаваемых беженцами или ходатайствующих о предоставлении убежища) с учётом состояния рынка труда, иммиграционных проблем, криминогенной обстановки и возможности жилищного обустройства иностранных граждан и лиц без гражданства в субъекте Российской Федерации. В настоящее время распоряжениями Правительства Российской Федерации ежегодно определяется квота на выдачу иностранным гражданам и лицам без гражданства разрешений на временное проживание в Российской Федерации, в которую не включаются граждане стран СНГ, пользующиеся правом безвизового въезда в Россию, и ряд других категорий иностранцев;

- урегулировать порядок финансирования депортации (выдворения) незаконных мигрантов за пределы Российской Федерации и расходования денежных средств на исполнение решений о нежелательности пребывания (проживания) иностранцев на территории России. В Федеральном законе «О правовом положении иностранных граждан в Российской Федерации» предусмотреть правила, в соответствии с которыми иностранные граждане и лица без гражданства при въезде в Российскую Федерацию вносили бы залоговую стоимость обратного авиабилета до столицы своего государства. При их своевременном выезде из России указанные деньги будут возвращаться, в противном случае - обращаться в доход государства, а затем использоваться на финансирование их депортации (выдворения) из России и исполнение решений о нежелательности пребывания (проживания) на территории Российской Федерации.

Как представляется, реализация предложенных мер может способствовать защите прав и законных интересов российских граждан и мигрантов, снижению рисков и минимизации угроз национальной безопасности Российской Федерации в миграционной сфере. 
доктор юридических наук, член Общественного консультативного научно-методического Совета при ЦИК России

109012, г. Москва, Б. Черкасский пер. д. 4 стр. 2 e-mail:vkr@fromru.com 